\title{
PENERAPAN ACTIVITY BASED COSTING SYSTEM DALAM LAPORAN KEUANGAN UNTUK MEMPERMUDAH PENGENDALIAN BIAYA
}

\author{
Euis Sitinur Aisyah ${ }^{1}$ \\ Padeli $^{2}$ \\ Sumasih $^{3}$ \\ Dosen AMIK Raharja ${ }^{1,2}$ \\ Alumni STMIK Raharja ${ }^{3}$ \\ Jl. Jendral Sudirman No. 40, Modern Cikokol-Tangerang \\ e-mail : euis@ raharja.info,padeli@raharja.info,sumasih@ raharja.info
}

\begin{abstract}
ABSTRAK
Teknologi komputer bisa mengolah data transaksi keuangan dan informasi berupa laporan keuangan yang dapat dijadikan sebagai informasi pendukung dalam pengambilan keputusan pada manajemen level atas untuk strategi keberlangsungan bisnis terutama dalam pengendalian biaya. Pada laporan keuangan rumah makan SM saat ini, sudah menggunakan database microsoft access namun masih terdapat kendala yaitu belum bisa merinci pengalokasian biaya overhead serta belum ada fasilitas button untuk menampilkan suatu record dengan menggunakan beberapa kondisi, misalnya menampilkan data pembelian bahan penunjang dengan alokasi untuk suatu produk dalam jangka waktu tertentu. Selain itu, laporan tersebut masih harus diolah kembali menggunakan Microsoft excell, sehingga ada dua kali proses untuk menyajikan data tersebut sebelum dijadikan laporan keuangan. Laporan keuangan dalam penelitian ini menggunakan metode activity based costing system. Metodologi penelitian yang digunakan yaitu analisis SWOT guna mengetahui kekuatan, kelemahan, peluang dan ancaman perusahaan dari segi internal dan eksternal serta strategi perusahaan. Perancangan sistem ini menggunakan tools UML(Unified Modeling Language) dan pengujian program yang diusulkan menggunakan Blackbox Testing. Sedangkan perancangan aplikasinya menggunakan bahasa pemrograman PHP (Hypertext Preprocessor) dengan Framework CodeIgniter (CI) dan pembuatan database menggunakan MySQL. Hasil penelitian ini adalah laporan keuangan yang mampu menampilkan informasi yang terinci dari pendapatan dan biaya overhead yang digunakan pada proses produksi setiap item yang meliputi proses dari bahan baku sampai menjadi bahan jadi siap jual, sehingga mudah mengetahui kemampuan laba yang dihasilkan dari setiap item yang diproduksi tersebut.
\end{abstract}

Kata Kunci : Activity Based Costing System, Laporan Keuangan, Pengendalian Biaya

\begin{abstract}
Computer technology can process data and financial transactions in the form of financial statements information that can be used as supporting information in decision-making at the top level management for business continuity strategy, especially in cost control. In the financial statements restaurant SM today, already uses Microsoft Access database, but there are obstacles that can not specify the allocation of overhead costs and no facilities button to show a record by using a number of conditions, such as displaying the data supporting the allocation of the purchase of materials for a product within a specified period. In addition, the report still has to be re-processed using Microsoft Excel, so that there are two processes to present the data before it made the financial statements . The financial statements in this study using activity based costing system. The research methodology used is a SWOT analysis to determine the strengths, weaknesses, opportunities and threats in terms of the company 's internal and external as well as corporate strategy. This system design using UML tools ( Unified Modeling Language) and the proposed testing program using Blackbox Testing.
\end{abstract}


While designing applications using PHP ( Hypertext Preprocessor) with CodeIgniter Framework ( $C I)$ and uses a MySQL database creation. The results of this study are the financial statements that can display detailed information on income and overhead costs that are used in the production process of each item that includes the process from raw materials into finished materials ready to sell , making it easy to determine the ability of the profit generated from each item produced.

Keywords : Financial Statements , activity based costing system, cost controlling

\section{PENDAHULUAN}

\section{Latar Belakang}

Perkembangan teknologi komputer yang canggih dibutuhkan dalam mekanisme pengolahan data dan penyajian laporan keuangan di setiap perusahaan. Melalui teknologi komputer kita bisa mengolah data dan mengakses informasi. Bagi manajemen, informasi ini bisa dijadikan sebagai pendukung pengambilan keputusan teutama pada manajemen level atas. Dimana dalam laporan keuangan tersebut akan terlihat bagaimana perusahaaan mempertahankan eksistensinya, serta pertumbuhan perusahaan dalam menjalankan usaha sesuai dengan perencanaan dan perhitungan yang detail dari semua transaksi keuangan.

Tujuan adanya laporan keuangan pada rumah makan SM adalah untuk mengetahui sejauh mana profit bisa dicapai. Selain itu, juga sebagai bahan pertimbangan bagi owner untuk membuat keputusan strategis atau kebijakan demi keberlangsungan rumah makan ini terutama dalam pengendalian biaya. Dilihat dari tujuan tersebut, laporan keuangan ini membutuhkan metode yang cocok untuk memenuhi kriteria laporan keuangan yang dibutuhkan oleh owner sehingga data bisa lebih cepat diolah dan ditelusuri.

Berdasarkan latar belakang tersebut maka dibuatlah penelitian tentang implementasi activity based costing system dalam laporan keuangan yang bertujuan untuk mempermudah pengendalian biaya pada rumah makan SM.

\section{ANALISA MASALAH}

\section{A. Rumusan Masalah}

Berikut ini beberapa hal yang menjadi analisa per masalahan dalam penelitian yang akan dibahas:

1. Bagaimana aplikasi laporan keuangan pada rumah makan SM yang berjalan saat ini?

2. Apakah sistem dan metode laporan keuangan yang berjalan saat ini bisa memberi laporan terinci terhadap perolehan laba atau rugi setiap item?

3. Bagaimana perancangan sistem laporan keuangan terintegrasi yang akan diaplikasikan pada rumah makan SM?

\section{B. Tujuan Penelitian}

Tujuan penelitian ini adalah sebagai berikut:

1. Menganalisa laporan keuangan pada rumah makan SM

2. Menganalisa metode activity based costing system dan merancang penerapannya pada laporan keuangan

3. Mempermudah penelusuran dan pengendalian biaya overhead produksi melalui laporan keuangan 


\section{ANALISA METODE PENELITIAN}

\subsection{Metode Penelitian}

Penelitian ini menggunakan beberapa tahap yang bisa dilihat pada gambar sebagai berikut:

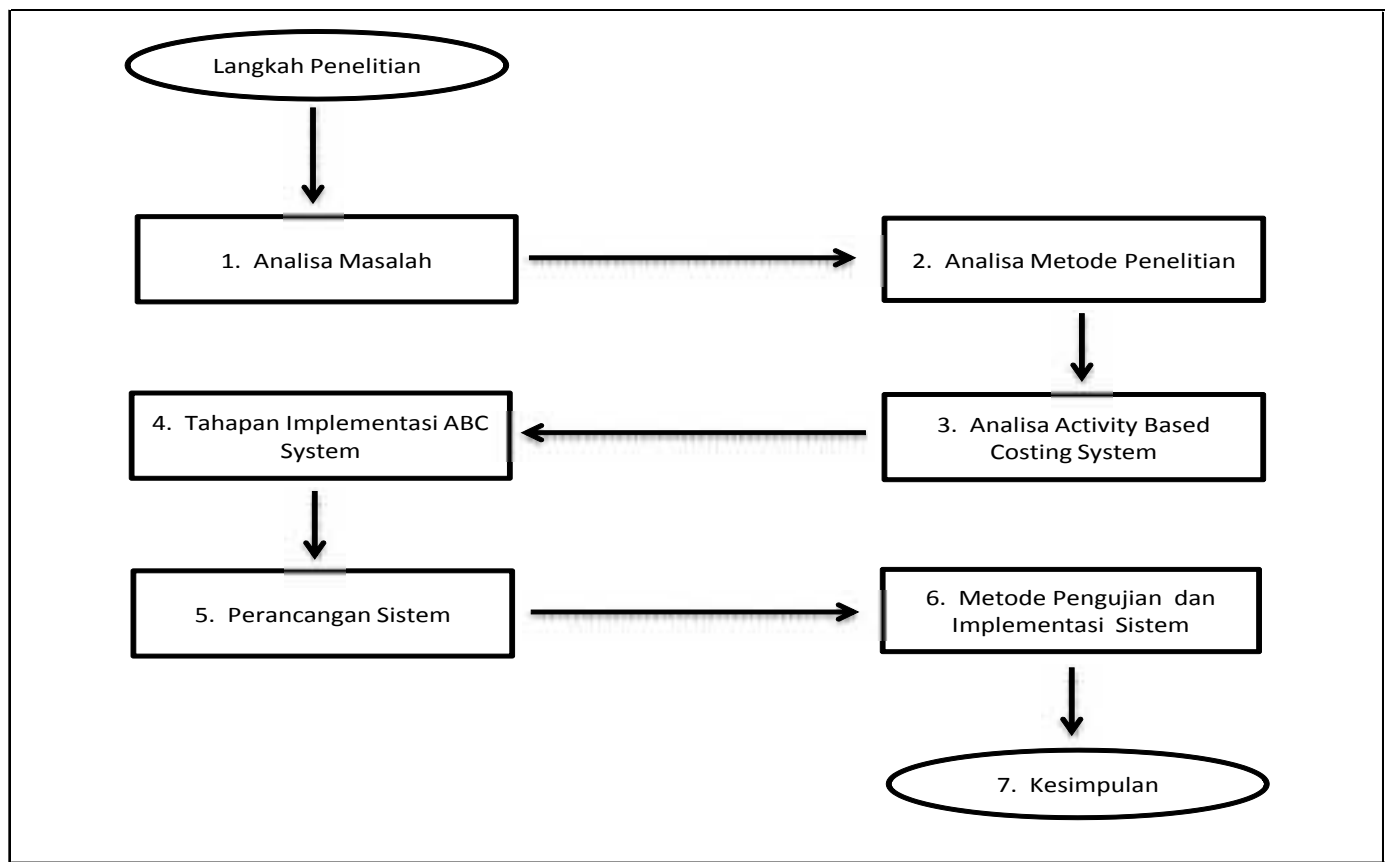

\section{Gambar 2.1. Tahapan Penelitian}

Dari gambar di atas, dapat dijelaskan tahapan penelitian ini, yaitu:

1. Penelitian ini dimulai dengan menganalisa masalah laporan keuangan yang dihadapi pada rumah makan SM. Dengan diawali mengidentifikasi masalah pada penelitian ini dengan merumuskan masalah, kemudian menetapkan tujuan dan bisa mengetahui metodologi yang mampu mengatasi masalah tersebut.

2. Melakukan analisa metode penelitian yakni dengan observasi ke rumah makan SM untuk mendapatkan data dan terlibat langsung dalam prosedur pembuatan laporan keuangan, mewawancarai user, dan mengumpulkan informasi dengan studi pustaka yang berkaitan dengan penelitian ini. Penelitian ini juga dilengkapi dengan analisis SWOT untuk mengetahui kekuatan, kelemahan, peluang dan ancaman perusahaan dari segi internal dan eksternal serta strategi perusahaan dalam menggunakan kekuatan dan peluang dengan meminimalisir kelemahan dan ancaman. Pada tahap ini juga dilakukan kajian pustaka atau literature review yang berkaitan dengan penelitian ini.

3. Setelah mendapatkan data yang cukup, maka tahap selanjutnya adalah menentukan dan menganalisa melalui penjabaran secara deskriptif tentang activity based costing system sebagai metode yang dinilai tepat dalam menghubungkan akuntansi biaya dan akuntansi manajemen sesuai dengan tujuan penelitian.

4. Kemudian dilanjutkan ke tahap penerapan sistem ABC sesuai dengan langkahlangkahnya.

5. Dari tahap implementasi sistem $\mathrm{ABC}$, lalu menyatukan sistem $\mathrm{ABC}$ ke perancangan sistem yang akan dibuat.

6. Sistem yang sudah dibuat masih harus diuji. Pengujian ini dilakukan dengan blackbox testing. Pengujian ini dimaksudkan untuk mengetahui dan memperbaiki perancangan sistem agar berjalan sesuai dengan fungsinya. Jika sistem lolos dari 
pengujian, maka sistem tersebut siap untuk diterapkan ke dalam lingkungan rumah makan SM.

7. Tahap akhir adalah membuat kesimpulan tentang penelitian ini.

\subsection{Literature Review}

Adapun beberapa studi pustaka yang berhubungan dengan topik penelitian ini antara lain: 


\section{ISSN: 2461-1409}

Table 2.1. Literature Review

\begin{tabular}{|c|c|c|c|c|c|c|c|}
\hline $\begin{array}{l}\text { Nama Dan } \\
\text { Tahun } \\
\text { Penelitian }\end{array}$ & $\begin{array}{l}\text { [Kamalia Tri } \\
\text { Utami, 2009] } \\
\text { STMIK } \\
\text { RAHARJA }\end{array}$ & $\begin{array}{l}\text { [Siti Saridatur } \\
\text { Rohmi, 2010] } \\
\text { STMIK } \\
\text { RAHARJA }\end{array}$ & $\begin{array}{c}\text { [Sudi Hartati, } \\
\text { 2010] } \\
\text { STMIK } \\
\text { RAHARJA }\end{array}$ & $\begin{array}{c}\text { [Lanang Sadewo, } \\
\text { 2013] } \\
\text { UIN Syarif } \\
\text { Hidayatullah }\end{array}$ & $\begin{array}{c}\text { [Koko Yuli } \\
\text { Prakoso, 2012] } \\
\text { UIN Sunan } \\
\text { Kalijaga } \\
\text { Yogyakarta }\end{array}$ & $\begin{array}{c}\text { [Yulianti, 2011] } \\
\text { Universitas } \\
\text { Hasanuddin } \\
\text { Makasar }\end{array}$ & $\begin{array}{l}\text { Penelitian } \\
\text { Penulis }\end{array}$ \\
\hline $\begin{array}{l}\text { Judul } \\
\text { Penelitian }\end{array}$ & $\begin{array}{l}\text { Perancangan } \\
\text { Sistem Informasi } \\
\text { Laporan } \\
\text { Keuangan APBD } \\
\text { Pada Dinas } \\
\text { Pendidikan } \\
\text { Menggunakan } \\
\text { Program Visual } \\
\text { Basic } 6.0\end{array}$ & $\begin{array}{l}\text { Perancangan } \\
\text { Sistem Informasi } \\
\text { Laporan } \\
\text { Keuangan Pada } \\
\text { PT. Tangerang } \\
\text { Tirta Manunggal }\end{array}$ & $\begin{array}{l}\text { Perancangan } \\
\text { Sistem Penyajian } \\
\text { Laporan } \\
\text { Realisasi } \\
\text { Anggaran Pada } \\
\text { Badan Pusat } \\
\text { Statistik Kota } \\
\text { Tangerang }\end{array}$ & $\begin{array}{l}\text { Design Penerapan } \\
\text { Activity Based } \\
\text { Costing System } \\
\text { Untuk } \\
\text { Menentukan } \\
\text { Harga Pokok } \\
\text { Produksi }\end{array}$ & $\begin{array}{l}\text { Penerapan } \\
\text { Metode Activity } \\
\text { Based Costing } \\
\text { (ABC) Dengan } \\
\text { Pendekatan } \\
\text { Manajemen } \\
\text { Rantai Pasok } \\
\text { (Supply Chain } \\
\text { Mangement) Di } \\
\text { Pt. Kawan Sejati } \\
\text { Akurasi }\end{array}$ & $\begin{array}{l}\text { Penerapan } \\
\text { Activity Based } \\
\text { Costing System } \\
\text { Sebagai Dasar } \\
\text { Penetapan Tarif } \\
\text { Jasa Rawat Inap }\end{array}$ & $\begin{array}{l}\text { Penerapan } \\
\text { Activity Based } \\
\text { Costing } \\
\text { System Dalam } \\
\text { Laporan } \\
\text { Keuangan } \\
\text { Untuk } \\
\text { Mempermudah } \\
\text { Pengendalian } \\
\text { Biaya }\end{array}$ \\
\hline $\begin{array}{l}\text { Objek } \\
\text { Penelitian }\end{array}$ & $\begin{array}{l}\text { Dinas Pendidikan } \\
\text { Kota Tangerang }\end{array}$ & $\begin{array}{l}\text { PT. Tangerang } \\
\text { Tirta Manunggal }\end{array}$ & $\begin{array}{l}\text { Badan Pusat } \\
\text { Statistik Kota } \\
\text { Tangerang }\end{array}$ & $\begin{array}{l}\text { CV.D elima } \\
\text { Mandiri }\end{array}$ & $\begin{array}{l}\text { PT. Kawan Sejati } \\
\text { Akurasi } \\
\text { Yogyakarta }\end{array}$ & $\begin{array}{l}\text { RSUD Sulthan } \\
\text { Daeng Radja } \\
\text { Kecamatan } \\
\text { Bulukumba }\end{array}$ & $\begin{array}{l}\text { Rumah Makan } \\
\text { SM }\end{array}$ \\
\hline $\begin{array}{l}\text { Identifikasi } \\
\text { Masalah }\end{array}$ & $\begin{array}{l}\text { Bagaimana } \\
\text { merancang sistem } \\
\text { informasi laporan } \\
\text { keuangan APBD }\end{array}$ & $\begin{array}{l}\text { Bagaimana } \\
\text { merancang } \\
\text { laporan } \\
\text { keuangan berupa } \\
\text { jurnal umum, } \\
\text { laporan laba rugi } \\
\text { dan neraca }\end{array}$ & $\begin{array}{l}\text { Bagaimana } \\
\text { merancang } \\
\text { sistem penyajian } \\
\text { laporan realisasi } \\
\text { anggaran }\end{array}$ & $\begin{array}{l}\text { Bagaimana } \\
\text { menerapkan ABC } \\
\text { dalam menentukan } \\
\text { HPP bagi produk } \\
\text { tube dan produk } \\
\text { dengan tutup botol }\end{array}$ & $\begin{array}{l}\text { Bagaimana } \\
\text { menerapkan ABC } \\
\text { dengan } \\
\text { pendekatan } \\
\text { supply chain } \\
\text { management }\end{array}$ & $\begin{array}{l}\text { Bagaimana } \\
\text { menerapkan } \\
\text { ABC dalam } \\
\text { menetapkan tarif } \\
\text { dasar rawat inap }\end{array}$ & $\begin{array}{l}\text { Bagaimana } \\
\text { merancang } \\
\text { sistem informasi } \\
\text { laporan keuangan } \\
\text { dengan } \\
\text { menggunakan } \\
\text { sistem ABC }\end{array}$ \\
\hline
\end{tabular}

Vol.2 No.2 - Agustus 2016 
ISSN: 2461-1409

\begin{tabular}{|c|c|c|c|c|c|c|c|}
\hline Metodologi & $\begin{array}{l}\text { Melakukan } \\
\text { observasi, } \\
\text { interview, dan } \\
\text { studi pustaka }\end{array}$ & $\begin{array}{l}\text { Melakukan } \\
\text { observasi, } \\
\text { interview, dan } \\
\text { studi pustaka }\end{array}$ & $\begin{array}{l}\text { Melakukan } \\
\text { observasi, } \\
\text { interview, dan } \\
\text { studi pustaka }\end{array}$ & $\begin{array}{l}\text { Melakukan analisa } \\
\text { deskriptif } \\
\text { terhadap data } \\
\text { kualitatif (dengan } \\
\text { perbandingan dua } \\
\text { sistem) dan } \\
\text { kuantitatif berupa } \\
\text { data angka-angka }\end{array}$ & $\begin{array}{l}\text { Penyampaian } \\
\text { gambar alur } \\
\text { kegiatan, alur dan } \\
\text { desain penelitian } \\
\text { dan melakukan } \\
\text { tahapan penelitian } \\
\text { dalam } \\
\text { menerapkan ABC }\end{array}$ & $\begin{array}{l}\text { Data diambil } \\
\text { dari hasil } \\
\text { interview, } \\
\text { observasi, } \\
\text { tinjauan pustaka } \\
\text { dan menganalisis } \\
\text { dengan metode } \\
\text { deskriptif } \\
\text { komparatif }\end{array}$ & $\begin{array}{l}\text { Melakukan } \\
\text { observasi, } \\
\text { magang dan } \\
\text { interview juga } \\
\text { dilengkapi } \\
\text { dengan studi } \\
\text { pustaka, serta } \\
\text { mendesain } \\
\text { tahapan } \\
\text { penerapan sistem } \\
\text { ABC }\end{array}$ \\
\hline $\begin{array}{l}\text { Nama Dan } \\
\text { Tahun } \\
\text { Penelitian }\end{array}$ & $\begin{array}{l}\text { [Kamalia Tri } \\
\text { Utami, 2009] } \\
\text { STMIK } \\
\text { RAHARJA }\end{array}$ & $\begin{array}{l}\text { [Siti Saridatur } \\
\text { Rohmi, 2010] } \\
\text { STMIK } \\
\text { RAHARJA }\end{array}$ & $\begin{array}{c}\text { [Sudi Hartati, } \\
\text { 2010] } \\
\text { STMIK } \\
\text { RAHARJA }\end{array}$ & $\begin{array}{c}\text { [Lanang Sadewo, } \\
2013 \text { ] } \\
\text { UIN Syarif } \\
\text { Hidayatullah }\end{array}$ & $\begin{array}{c}\text { [Koko Yuli } \\
\text { Prakoso, 2012] } \\
\text { UIN Sunan } \\
\text { Kalijaga } \\
\text { Yogyakarta }\end{array}$ & $\begin{array}{c}\text { [Yulianti, 2011] } \\
\text { Universitas } \\
\text { Hasanuddin } \\
\text { Makasar }\end{array}$ & $\begin{array}{l}\text { Penelitian } \\
\text { Penulis }\end{array}$ \\
\hline $\begin{array}{l}\text { Model } \\
\text { Sistem }\end{array}$ & $\begin{array}{l}\text { Rancangan } \\
\text { menggunakan } \\
\text { Object Oriented } \\
\text { Analysis and } \\
\text { Design (OOAD) } \\
\text { dengan tools UML } \\
\text { (sequence } \\
\text { diagram, usecase } \\
\text { diagram dan } \\
\text { activity diagram) }\end{array}$ & $\begin{array}{l}\text { Rancangan } \\
\text { menggunakan } \\
\text { Object Oriented } \\
\text { Analysis and } \\
\text { Design (OOAD) } \\
\text { dengan tools } \\
\text { UML (sequence } \\
\text { diagram, } \\
\text { usecase diagram } \\
\text { dan activity } \\
\text { diagram) }\end{array}$ & $\begin{array}{l}\text { Rancangan } \\
\text { menggunakan } \\
\text { Object Oriented } \\
\text { Analysis and } \\
\text { Design (OOAD) } \\
\text { dengan tools } \\
\text { UML (sequence } \\
\text { diagram, } \\
\text { usecase diagram } \\
\text { dan activity } \\
\text { diagram) }\end{array}$ & $\begin{array}{l}\text { Menggunakan } \\
\text { Activity Based } \\
\text { Costing System } \\
\text { dalam menetukan } \\
\text { HPP }\end{array}$ & $\begin{array}{l}\text { Menggunakan } \\
\text { Activity Based } \\
\text { Costing System }\end{array}$ & $\begin{array}{l}\text { Menggunakan } \\
\text { Activity Based } \\
\text { Costing System } \\
\text { pada tarif dasar } 4 \\
\text { kelas yang } \\
\text { fasilitasnya } \\
\text { berbeda }\end{array}$ & $\begin{array}{l}\text { Menggunakan } \\
\text { Activity Based } \\
\text { Costing System } \\
\text { pada akun } \\
\text { pendapatan dan } \\
\text { pengeluaran } \\
\text { berdasarkan jenis } \\
\text { alokasinya }\end{array}$ \\
\hline
\end{tabular}


ISSN: 2461-1409

\begin{tabular}{|c|c|c|c|c|c|c|c|}
\hline $\begin{array}{l}\text { Hasil } \\
\text { Sistem }\end{array}$ & $\begin{array}{l}\text { Penginputan data } \\
\text { kas masuk } \\
\text { menjadi lebih } \\
\text { valid dalam } \\
\text { transaksi } \\
\text { pendapatan karena } \\
\text { fokus pada satu } \\
\text { bahasan saja yakni } \\
\text { di penginputan } \\
\text { pendapatan } \\
\text { sehingga } \\
\text { pelaporan jadi } \\
\text { lebih ringkas dan } \\
\text { akurat. }\end{array}$ & $\begin{array}{l}\text { Kecepatan dan } \\
\text { ketepatan dalam } \\
\text { membuat } \\
\text { laporan } \\
\text { keuangan bisa } \\
\text { dihasilkan serta } \\
\text { dapat } \\
\text { menghindari } \\
\text { redudance } \\
\text { dalam data } \\
\text { sehingga mudah } \\
\text { dalam menusuri } \\
\text { data }\end{array}$ & $\begin{array}{l}\text { Data yang } \\
\text { dihasilkan lebih } \\
\text { akurat dan tidak } \\
\text { membutuhkan } \\
\text { sistem yang } \\
\text { lebih luas } \\
\text { cakupannya } \\
\text { karena fokus } \\
\text { pada akun } \\
\text { pengeluaran. }\end{array}$ & \begin{tabular}{lr}
\multicolumn{2}{l}{ Dengan } \\
menggunakan \\
Activity $\quad$ Based \\
Costing & System, \\
presisi & dalam \\
menentukan & HPP \\
menjadi r lebih \\
mendekati ran \\
lebih \\
memaksimalkan \\
labar dengan \\
pembebanan biaya \\
overhead yang \\
tepat.
\end{tabular} & $\begin{array}{l}\text { supply chain } \\
\text { management } \\
\text { dapat } \\
\text { mengintegrasikan } \\
\text { biaya distribusi } \\
\text { sejak dari } \\
\text { pemasok, } \\
\text { manufaktur dan } \\
\text { retailer sehingga } \\
\text { barang dapat } \\
\text { diproduksi dan } \\
\text { didistribusikan } \\
\text { dengan jumlah } \\
\text { yang tepat dan } \\
\text { biaya minimum. }\end{array}$ & $\begin{array}{l}\text { Studi kasus ini } \\
\text { menghasilkan } \\
\text { tarif dasar rawat } \\
\text { inap yang lebih } \\
\text { akurat } \\
\text { berdasarkan } \\
\text { kelas pelayanan } \\
\text { dengan } \\
\text { pembebanan } \\
\text { aktivitas sesuai } \\
\text { fasilitas per } \\
\text { kelas. }\end{array}$ & $\begin{array}{l}\text { Sistem informasi } \\
\text { laporan keuangan } \\
\text { bisa ditelusuri } \\
\text { berdasarkan } \\
\text { alokasi } \\
\text { penggunaannya } \\
\text { di setiap item } \\
\text { menu yang } \\
\text { diproduksi }\end{array}$ \\
\hline
\end{tabular}

Tabel 2.1 adalah tabel yang menjelaskan atau merinci beberapa pustaka yang dijadikan sebagai kajian pustaka oleh peneliti. Penelitian-penelitian tersebut memiliki tema yang berkaitan dengan penelitian ini. 
Penelitian ini berbeda dari enam penelitian sebelumnya yang dijadikan sebagai perbandingan, mengacu pada kebutuhan laporan keuangan secara umum dan tujuan perusahaan secara spesifik, perancangan sistem laporan keuangan ini mengkombinasikan activity based costing system dalam akun pendapatan dan pembelian di setiap transaksi agar diketahui jumlah biaya yang dialokasikan untuk menciptakan atau memproduksi setiap item menu di rumah makan tersebut. Sehingga sistem ABC ini tidak semata-mata untuk melihat atau bertujuan menentukan tarif dasar atau harga pokok sebuah produk seperti yang dilakukan oleh Lanang Sadewo, Koko Yuli Prakoso dan Yulianti tapi juga tidak hanya melaporkan data keuangan secara umum saja seperti penelitian-penelitian pada Kamalia Tri Utami, Siti Saridatur Rohmi dan Sudi Hartati. Dengan kata lain ini bisa menjadi alat bantu atau bahan pertimbangan dalam membuat keputusan stratejik di bagian produksi. Diharapkan dari kombinasi sistem ini, owner bisa mengendalikan biaya yang tidak mempunyai nilai tambah bagi keberlangsungan bisnis rumah makan tersebut.

\subsection{Analisa SWOT}

Di bawah ini adalah analisis swot terhadap sistem laporan keuangan yang sedang berjalan yang diharapkan bisa membantu dalam menentukan strategi yang efektif bagi perusahaan.

Tabel 2.1. Analisis SWOT

\begin{tabular}{|c|c|c|}
\hline & Positive & negative \\
\hline $\begin{array}{c}\text { Internal } \\
\text { Factors }\end{array}$ & $\begin{array}{l}\text { Strenghts: } \\
\text { 1. Sumber daya berkualifikasi } \\
\text { dan komunikasi yang baik } \\
\text { 2. Tersedianya sarana pendukung } \\
\text { informasi dan komunikasi } \\
\text { seperti tersedianya free wi-fi }\end{array}$ & $\begin{array}{l}\text { Weaknesses: } \\
\text { 1. } \\
\text { Kurang optimalnya } \\
\text { pemanfaatan teknologi } \\
\text { informasi untuk } \\
\text { kepentingan } \\
\text { administrasi bisnis. } \\
\text { 2. } \begin{array}{l}\text { Promosi yang belum } \\
\text { maksimal }\end{array} \\
\end{array}$ \\
\hline $\begin{array}{c}\text { External } \\
\text { Factors }\end{array}$ & $\begin{array}{l}\text { Opportunities: } \\
\text { 1. Produk telah memiliki banyak } \\
\text { pelanggan tetap. } \\
\text { 2. Belum banyak rumah makan } \\
\text { yang menjual produk yang } \\
\text { sama } \\
\text { 3. Perkembangan teknologi yang } \\
\text { sangat pesat. }\end{array}$ & $\begin{array}{l}\text { Threats: } \\
\text { 1. Harga bahan baku yang } \\
\text { meningkat } \\
\text { signifikan } \\
\text { 2. Adanya gangguan pada } \\
\text { keamanan data }\end{array}$ \\
\hline
\end{tabular}

Tabel 2.1 adalah analisis SWOT terhadap sistem laporan keuangan yang sedang berjalan saat ini diantaranya adalah:

1. Rumah makan SM memiliki kekuatan yakni sumber daya manusia yang cakap dalam komunikasi dan memiliki skill dalam menciptakan rasa masakan khas jawa yang unik dan lezat. Sumber daya ini diperkuat dengan kemampuan komunikasi yangn baik 
anatara pegawai dan pelanggan. Untuk membuat pelanggan betah selama berada di lingkungan SM, maka disediakan televisi dan free wi-fi.

2. Ketersediaan wifi di lokasi ini, belum digunakan untuk kirim data bisnis. Ini merupakan kelemahan. Sedangkan untuk promosi sudah diaplikasikan via internet, namun belum maksimal. Karena masih sedikit website yang digunakan untuk promosi.

3. Peluang yang dimiliki adalah banyak kesempatan untuk membuka cabang mengingat belum terlalu banyak yang memiliki brand ini. Cita rasa yang kuat dan khas membuat rumah makan SM memiliki banyak pelanggan setia dan kebanyakan dari kalangan ekonomi menengah ke atas (pelanggan potensial). Sehingga dari segi konsumen yang potensial, bisa meningkatkan omzet bisnis dengan memanfaatkan teknologi seperti internet.

4. Harga bahan baku yang sangat tergantung pada kenaikan BBM, menyebabkan biaya produksi meningkat jika terjadi kenaikan BBM. Dan ini merupakan ancaman bagi produksi rumah makan jika tidak mampu mengendalikan atau membuat strategi yang jitu dalam menghadapinya. Karena itu, sistem laporan keuangan yang mampu membantu dalam menganalisa laporan sangat dibutuhkan. Sistem ini juga harus mampu menangkal adanya bahaya pada keamanan data.

Dari analisis tersebut, selanjutnya dijelaskan strateginya yang bisa dilihat dari tabel di bawah ini:

Tabel 2.2. SWOT Matrix

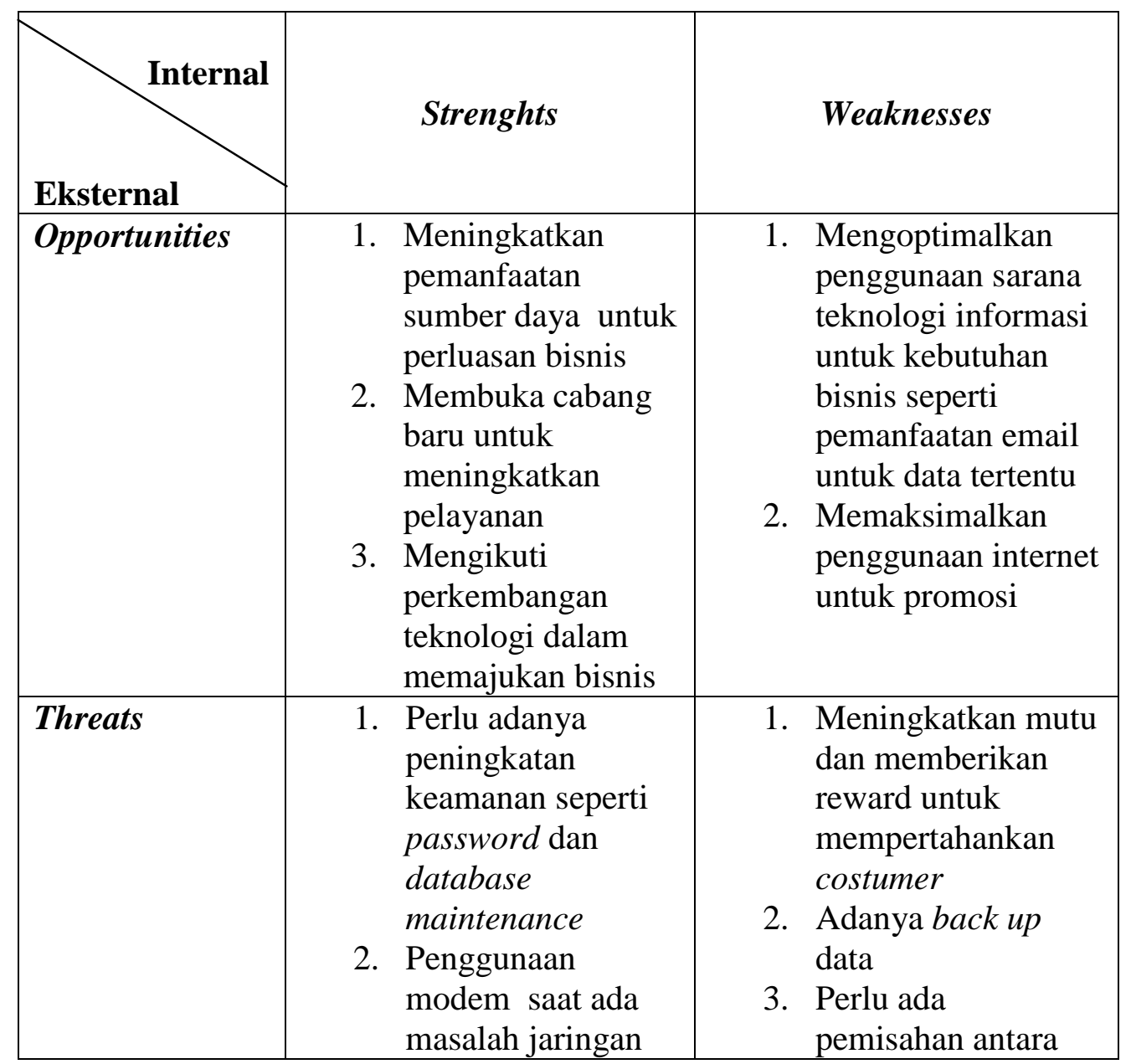




\begin{tabular}{|l|l|}
\hline wi-fi & $\begin{array}{l}\text { sistem informasi } \\
\text { untuk transaksi dan } \\
\text { analisis akuntansi }\end{array}$ \\
\hline
\end{tabular}

Pada tabel 2.2. menjelaskan SWOT matrix sebagai strategi dalam analisis SWOT, diantaranya:

1. Dengan menggunakan kekuatan dan memanfaatkan peluanga yang ada maka rumah makan SM harus meningkatkan pemanfaatan sumber daya manusia dan peralatan untuk perluasan bisnis dengan membuka cabang baru supaya bisa meningkatkan pelayanan bagi pelanggan di berbagai kota besar serta mengikuti perkembangan teknologi dalam memajukan bisnis.

2. Dalam mengatasi kelemahan untuk mendapatkan peluang, maka rumah makan SM harus mengoptimalkan penggunaan sarana teknologi informasi untuk kebutuhan bisnis atau pengiriman data seperti pemanfaatan email untuk data tertentu dan maksimalkan penggunaan internet untuk promosi sehingga bisa menjangkau lebih banyak lagi konsumen.

3. Dari kekuatan dan mengatasi ancaman, perlu adanya peningkatan keamanan seperti password dan database maintenance supaya data tidak bisa di-hack, namun jikaterjadi masalah jaringan komputer, harus ada penggunaan modem saat ada masalah jaringan wi-fi.

4. Mengatasi ancaman dan memanipulasi kelemahan yang dimiliki, maka harus meningkatkan mutu dan memberikan reward untuk mempertahankan costumer serta adanya back up data. Selain itu, perlu ada pemisahan antara sistem informasi untuk transaksi dan analisis akuntansi. Sehingga sistem menjadi lebih rapi.

\section{ANALISA ACTIVITY BASED COSTING SYSTEM}

\section{A. Definisi Activity Based Costing system}

Menurut Rudianto (2013:160)[1], “Activity Based Costing adalah pendekatan penentuan biaya produk yang membebankan ke produk atau jasa berdasarkan konsumsi sumber daya oleh aktivitas."

Dasar pemikiran pendekatan penentuan biaya ini adalah bahwa produk atau jasa perusahaan dilakukan oleh aktivitas, dan aktivitas yang dibutuhkan tersebut menggunakan sumber daya yang menyebabkan timbulnya biaya. Sumber daya dibebankan ke aktivitas kemudian aktivitas dibebankan ke objek biaya berdasarkan penggunaannya.

Menurut Simamora (2002:125)[2], "aktivitas (Activity) adalah setiap kejadian atau transaksi yang memicu biaya (cost driver) yakni, bertindak sebagai faktor penyebab (casual factor) dalam pengeluaran biaya di dalam organisasi".

Aktivitas dapat berupa tindakan, gerakan ataupun urutan pekerjaan. Aktivitas dapat juga diartikan sebagai tindakan yang dilakukan di dalam sebuah organisasi yang berfaedah untuk tujuan penentuan biaya pokok dasar aktivitas. Ada dua tahap dalam menentukan biaya pokok berdasarkan aktivitas, yaitu:

a. Biaya ditelusuri ke aktivitas

b. Aktivitas tadi lantas ditelusuri ke produk berdasarkan penggunaan aktivitas oleh produk tadi

Masih menurut Simamora (2002:125)[2], "Activity Based Costing system adalah sistem akuntansi yang terfokus pada aktivitas-aktivitas yang dilakukan untuk menghasilkan produk atau jasa." 
Dari beberapa definisi di atas, bisa disimpulkan bahwa Activity Based Costing system adalah sistem informasi akuntansi yang menjadikan aktivitas atau transaksi sebagai penyebab adanya biaya untuk menghasilkan produk atau jasa sehingga perusahaan bisa berjalan sesuai fungsinya. Sistem informasi ini lebih terfokus pada bagaimana perusahaan mengetahui harga pokok suatu barang atau jasa secara akurat dan mampu menghasilkan laba, juga dapat menjadi bahan pertimbangan untuk pengendalian biaya terutama biaya overhead.

$\mathrm{ABC}$ menyediakan informasi perihal aktivitas dan sumber daya yang dibutuhkan untuk melaksanakan aktivitas tersebut. Sistem ABC juga membantu perusahaan memperoleh informasi biaya produk yang lebih akurat. Sistem informasi ini diterapkan dalam perusahaan manufaktur, jasa, dan dagang. Sistem ini dirancang atas dasar landasan pikiran produk yang memerlukan aktivitas dan aktivitas mengkonsumsi sumber daya.

Rudianto (2013: 160)[1], mendefinisikan beberapa istilah dalam sistem ini, antara lain:

1. Sumber daya adalah unsur ekonomis yang dibebankan atau digunakan dalam pelaksanaan aktivitas. Contohnya gaji karyawan dan bahan baku.

2. Unsur biaya adalah jumlah yang dibayarkan untuk sumber daya yang dikonsumsi oleh aktivitas dan terkandung dalam cost-pool

3. Cost-pool adalah aktivitas tertentu dimana biaya dikelompokan. Departemen pada perusahaan sering kali merupakan cost-pool. Misanya departemen perakitan atau pengepakan menjadi cost pool untuk biaya penanganan bahan, biaya pengepakan, biaya supervisi, biaya pemakaian motor listrik dan sebagainya.

4. Cost driver (pemicu biaya) adalah faktor-faktor yang menyebabkan perubahan biaya aktivitas. Cost driver merupakan faktor yang dapat diukur yang digunakan untuk membebankan biaya ke aktivitas, dan dari aktivitas ke aktivitas lainnya, produk dan jasa.

5. Objek biaya adalah produk, jasa atau unit organisasi dimana biaya dibebankan untuk beberapa tujuan manajemen. Produk dan jasa pada umumnya merupakan objek biaya. Misalnya sebuah produsen mesin cuci dan lemari es akan menjadikan kedua produk tersebut menjadi objek biaya.

Penggunaan dari ABC ini, perusahaan dapat mengurangi atau menghilangkan aktivitas-aktivitas yang dianggap tidak membuat produk memiliki nilai tambah atau tidak membuat loyalitas pelanggan menjadi lebih tinggi.

\section{B. Konsep Dasar Activity Based Costing System}

Pendapat Simamora (2002:127), konsep-konsep dasar yang mendasari ABC dapat diringkas dalam dua hal, yaitu:

1) Aktivitas-aktivitas yang dilakukan untuk memenuhi kebutuhan akan mengkonsumsi sumber daya yang memerlukan uang. Manajer mengidentifikasikan aktivitas-aktivitas utama yang dilakukan oleh setiap departemen serta sumber daya yang dikonsumsinya, dan lantas memilih pemicu biaya untuk setiap aktivitas tersebut. Pemicu biaya harus merupakan ukuran yang terkuantifikasi dari apa yang menyebabkan sumber daya tadi digunakan.

2) Biaya sumber daya yang dikonsumsi oleh aktivitas haruslah dibebankan kepada objek biaya berdasarkan unit aktivitas yang dikonsumsi oleh objek biaya tersebut. Pemicu biaya dipakai untuk mengalokasikan biaya ke produk dan jasa. 
Mengenali dan mengidentifikasi hal-hal yang dapat menjadi pemicu biaya adalah sangat penting. Secara umum ada dua jenis pemicu biaya menurut Rudianto (2013:161)[1], yaitu:

a) Pemicu sumber daya (resource driver)

Ini adalah ukuran kuantitas sumber daya yang dikonsumsi oleh aktivitas. Pemicu sumber daya digunakan untuk membebankan biaya sumber daya yang dikonsumsi oleh aktivitas ke cost pool tertentu, contoh cost driver jenis ini adalah luas lantai pabrik, jumlah tenaga kerja, jumlah kamar yang tersedia.

b) Pemicu aktivitas (activity driver)

Ini adalah frekuensi dan intensitas permintaan suatu aktivitas terhadap objek biaya. Pemicu biaya aktivitas digunakan untuk membebankan biaya dari cost pool ke objek biaya, contohnya adalah jumlah suku cadang yang berbeda yang digunakan dalam produk akhir untuk mengukur konsumsi aktivitas penanganan bahan atas setiap produk.

\section{Syarat Penerapan Activity Based Costing System}

Sebuah perusahaan bisa menerapkan Activity Based Costing system jika memenuhi syarat sebagai berikut:

a. Perusahaan mempunyai tingkat diversitas/keragaman yang tinggi

Sistem ABC mensyaratkan bahwa perusahaan memproduksi beberapa macam produk atau lini produk yang diproses dengan menggunakan fasilitas yang sama. Kondisi yang demikian tentunya akan menimbulkan masalah dalam membebankan biaya ke masing-masing produk.

b. Tingkat persaingan industri yang tinggi

Yaitu terdapat beberapa perusahaan yang menghasilkan produk yang sama atau sejenis. Dalam persaingan antar perusahaan yang sejenis tersebut maka perusahaan akan semakin meningkatkan persaingan untuk memperbesar pasarnya. Semakin besar tingkat persaingan maka semakin penting peran informasi tentang harga pokok dalam mendukung pengambilan keputusan manajemen.

c. Biaya pengukuran yang rendah

Yaitu bahwa biaya yang digunakan sistem $\mathrm{ABC}$ untuk menghasilkan informasi biaya yang akurat harus lebih rendah dibandingkan dengan manfaat yang diperoleh.

\section{Definisi Laporan Keuangan}

Menurut Ramdhani (2011:73)[3], "laporan keuangan adalah suatu penyajian terstruktur dari posisi keuangan dan kinerja keuangan suatu entitas. Tujuan laporan keuangan adalah memberikan informasi mengenai posisi keuangan, kinerja keuangan dan arus kas entitas yang bermanfaat bagi sebagian besar kalangan pengguna laporan dalam pembuatan keputusan ekonomi."

\section{E. Korelasi Analisa Masalah, Tujuan Penelitian Dan Activity Based Costing System Pada Laporan Keuangan}

Jika dilihat dari rumusan masalah dan tujuan penelitian, kemudian dengan memahami definisi sistem ABC, konsep dasarnya dan syarat penerapan sistem ABC serta definisi laporan keuangan, maka bisa ditarik kesimpulan bahwa ada kesesuaian antara rumusan masalah dan tujuan penelitian dengan definisi sistem $\mathrm{ABC}$, konsep dasar sistem ABC dan syaratnya. 
Sistem ABC bisa memberikan laporan terinci pada perolehan laba atau rugi per item yang diproduksi. Biaya overhead juga mudah ditelusuri dan diminimalisir atau dikendalikan. Ini karena sistem $\mathrm{ABC}$ didasari pada penelusuran biaya yang dibutuhkan dalam aktivitas produksi, lalu biaya tersebut dibebankan ke produk. Karena setiap produk melalui proses yang berbeda, sehingga pembebanan biayapun akan berbeda di setiap produk. Dengan melihat selisih antara hasil penjualan dan jumlah beban biaya per produk, maka akan diketahui sejauh mana suatu produk bisa menghasilkan laba yang signifikan. Bila laba/rugi dihasilkan dari selisih, maka biaya konsumsi produk bisa dilihat dari biaya aktivitas-aktivitas yang terjadi dalam seluruh proses produksi yang dibebankan ke produk. Dari hasil analisa tersebutlah, mudah dalam pengendalian biaya overhead.

Dari uraian di atas, maka sistem ABC diyakini cocok untuk diimplementasikan pada laporan keuangan di lingkungan rumah makan SM.

\section{Tahapan Penerapan Activity Based Costing System}

Ada dua tahap dalam pengimplementasian Activity Based Costing system ini, yang bisa dilihat pada gambar berikut:

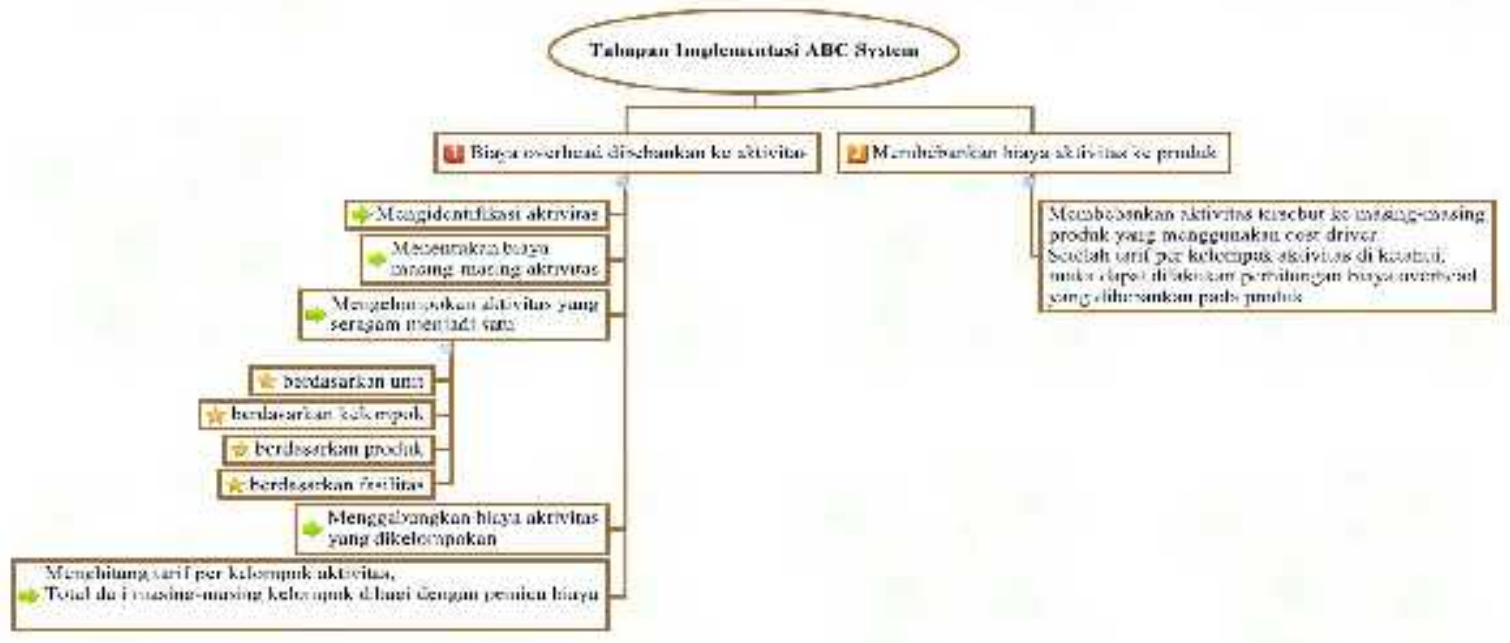

Gambar 4.1. Tahapan Implementasi ABC System

Berdasarkan gambar di atas, tahapan implementasi sistem $\mathrm{ABC}$ adalah sebagai berikut:

1. Tahap pertama adalah membebankan seluruh biaya overhead ke aktivitas dengan melalui langkah sebagai berikut:

a. Langkah pertama adalah mengidentifikasi aktivitas yang ada di seluruh proses produksi sejak awal hingga barang sampai ke pelanggan dengan cara:

a.1. Menetapkan proses aktivitas produksi dari pemesanan bahan baku sampai barang jadi siap jual, pada penelitian ini aktivitas-aktivitas tersebut dibagi menjadi aktivitas pembelian bahan baku, aktivitas proses produksi bahan baku jadi produk jadi siap jual, aktivitas penjualan, aktivitas pengepakan/pembungkusan, aktivitas pelayanan, aktivitas pengiriman barang dan aktivitas promosi. Dalam langkah ini sebagai contohnya adalah seluruh biaya yang meliputi aktivitas pembelian bahan baku termasuk beban solar/bensin saat proses pembelian bahan baku akan dibebankan oleh aktivitas 
pembelian bahan baku. Sedangkan beban solar/bensin saat pengiriman barang dari pusat ke cabang, akan dibebankan dalam aktivitas pengiriman barang.

a.2.Kemudian akan diketahui jumlah biaya yang dibebankan oleh semua aktivitas masing-masing dan akan bisa ditelusuri aktivitas mana yang menggunakan biaya yang dianggap kurang memberi nilai tambah pada suatu produk. Contohnya seberapa besar biaya parkir dalam aktivitas pembelian bahan baku. Dari langkah ini, maka owner bisa membuat keputusan mengubah strategi dalam pembelian bahan baku untuk meminimalisir biaya parkir.

b. Menentukan biaya masing-masing aktivitas

Tahap selanjutnya adalah menentukan atau menghitung biaya masing-masing aktivitas yang ada di seluruh proses produksi, seperti berapa biaya aktivitas pembelian bahan baku, biaya aktivitas proses produksi dari bahan baku menjadi barang jadi siap jual, biaya pengepakan, biaya pengiriman sampai produk ke tangan pelanggan serta biaya promosi.

c. Mengelompokan aktivitas yang seragam menjadi satu, dengan menganalisa aktivitas mana yang pembebanan biayanya:

c.1. Berdasarkan unit, contohnya pada aktivitas pemesanan bahan baku ada biaya pengiriman yang dihitung berdasarkan unit.

c.2. Berdasarkan kelompok (batch), contohnya pada aktivitas pengepakan/pembungkusan produk, biaya pembungkusan dibebankan perkelompok produk. Seperti biaya pembungkusan soto daging dan soto ayam dimasukan ke dalam aktivitas pembungkusan soto. Sedangkan pembungkusan sate ayam dan sate kambing dimasukan ke dalam aktivitas pembungkusan sate.

c.3. Berdasarkan produk, contohnya pada aktivitas proses produksi dibuat beberapa kelompok berdasarkan jenis menunya. Aneka soto daging dimasukan ke jenis menu soto daging. Aneka jenis sate dimasukan ke jenis menu sate. Begitu pula dengan aneka kerupuk dijadikan jenis kerupuk.

c.4. Terakhir, berdasarkan fasilitas. Contohnya, pada pembelian bahan baku menggunakan kendaraan yang memerlukan biaya bahan bakar yang sama atau penggunaan mesin yang sama untuk beberapa jenis produk tanpa melihat penggolongan unit, kelompok atau produknya.

d. Biaya untuk masing-masing kelompok (unit, batch level, product dan facility sustaining) dijumlahkan sehingga dihasilkan total biaya untuk tiap-tiap kelompok.

e. Menghitung tarif per kelompok aktivitas dengan cara membagi jumlah total biaya pada masing-masing kelompok dengan jumlah cost driver atau pemicu biaya.

2. Tahap kedua yakni tahap terakhir adalah membebankan biaya aktivitas ke produk. Yakni tahap ke dua dalam pengimplementasian yang dimulai dari membebankan biaya aktivitas tersebut ke masing-masing produk yang menggunakan pemicu biaya (cost driver). Setelah diketahui biaya perkelompok aktivitas, maka biaya itu dibebankan ke produk.

\section{PERANCANGAN SISTEM}

\subsection{Metodologi Perancangan}

Proses perancangan sistem ABC laporan keuangan di rumah makan SM meliputi pembuatan model dengan menggunakan tools UML (Unified Modeling Language) yaitu Use Case Diagram dengan software Visual Paradigm 6.4 enterprise edition. Serta menggunakan bahasa pemrograman PHP (PHP Hypertext 
Preprocessor) dengan Framework CodeIgniter (CI) dan pembuatan database pada MySQL.

Berikut ini adalah use case diagram sistem yang akan di buat:

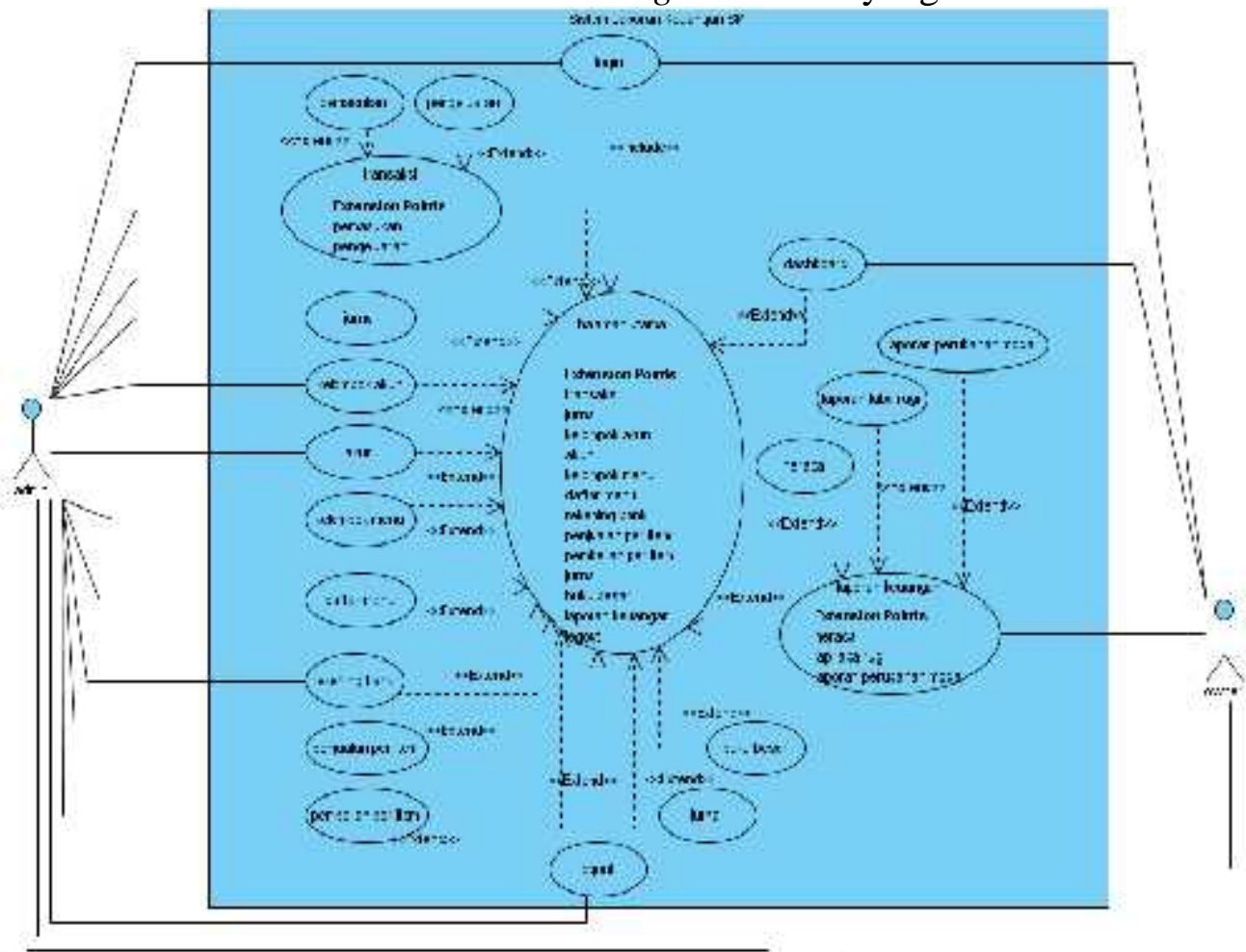

Gambar 5.1. Use Case Diagram Sistem ABC dalam Laporan Keuangan SM terdapat:

Berdasarkan gambar 5.1. Use Case Diagram sistem ABC pada laporan keuangan

a. 1 (satu) system, mencakup seluruh kegiatan laporan keuangan di rumah makan SM

b. 2 (dua) actor, melakukan kegiatan diantaranya: admin dan owner

c. 21 (dua puluh satu) use case, yang dilakukan diantaranya: login, halaman utama, transaksi, pemasukan, pengeluaran, jurnal, kelompok akun, akun, kelompok menu, daftar menu, rekening bank, penjualan per item, pembelian per item, jurnal, buku besar, laporan keuangan, neraca, laporan laba rugi, laporan perubahan modal, dashboard dan log out.

d. Sistem ABC akan diterapkan pada use case kelompok menu dan daftar menu untuk meng-input hasil dari analisa sistem ABC. Setelah input transaksi pemasukan dan pengeluaran pada form transaksi dilakukan, maka hasil analisa sistem $\mathrm{ABC}$ bisa ditampilkan pada use case penjualan per item dan pengeluaran per item.

\subsection{Metodologi Testing}

Dalam hal ini proses pengujian sistem $\mathrm{ABC}$ laporan keuangan di rumah makan SM menggunakan metodologi Blackbox Testing. Blackbox Testing adalah metodologi uji coba yang memfokuskan pada keperluan fungsional perangkat lunak. Pengujian blackbox berusaha menemukan fungsi-fungsi yang tidak benar atau hilang, kesalahan interface, kesalahan dalam struktur data atau akses database eksternal, kesalahan kinerja dan inisialisasi dan kesalahan terminasi. 


\section{METODE PENGUJIAN DAN IMPLEMENTASI SISTEM}

\subsection{Pengujian Sistem}

Pengujian sistem ini dilakukan dengan blackbox testing untuk menguji kesesuaian rancangan fungsional aplikasi dengan tampilan dan jalannya aplikasi apakah aplikasi sesuai dengan rancangan fungsional dan memiliki error atau tidak. Pengujian blackbox testing pada sistem ini didefinisikan melalui tabel berikut: 
ISSN: 2461-1409

Tabel 6.1. Blackbox Testing

\begin{tabular}{|c|c|c|c|c|c|}
\hline No & $\begin{array}{l}\text { Skenario } \\
\text { Pengujian }\end{array}$ & Test Case & $\begin{array}{l}\text { Hasil Yang } \\
\text { Diharapkan }\end{array}$ & Hasil Pengujian & Kesimpulan \\
\hline 1 & $\begin{array}{l}\text { Berhasil } \\
\text { melakukan } \\
\text { login. }\end{array}$ & 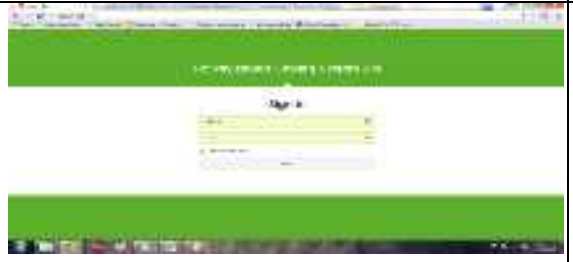 & $\begin{array}{l}\text { Sistem berhasil } \\
\text { masuk ke } \\
\text { halaman utama. }\end{array}$ & 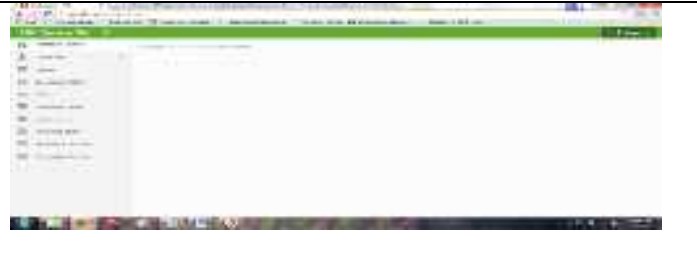 & Valid \\
\hline 2 & $\begin{array}{l}\text { Berhasil } \\
\text { input akun }\end{array}$ & 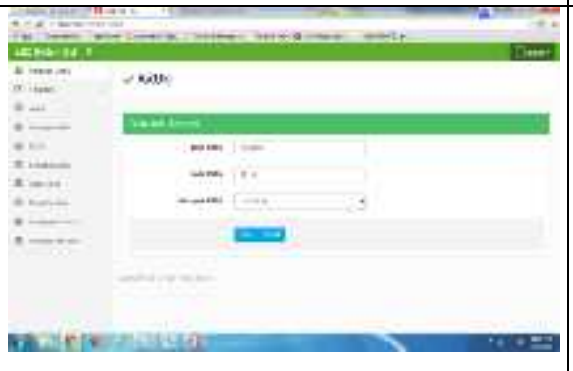 & $\begin{array}{l}\text { Data akun tampil } \\
\text { pada list akun }\end{array}$ & 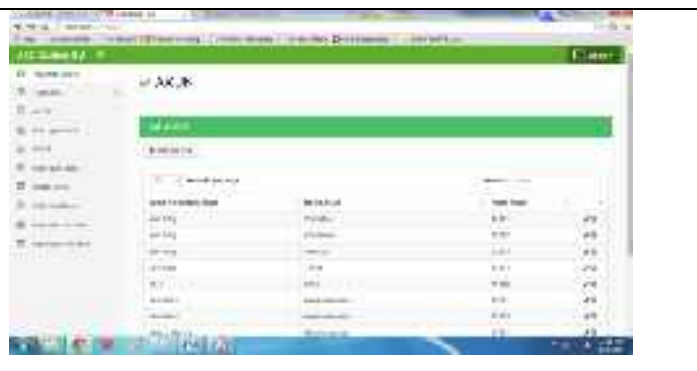 & Valid \\
\hline 3 & $\begin{array}{l}\text { Berhasil } \\
\text { input daftar } \\
\text { menu }\end{array}$ & 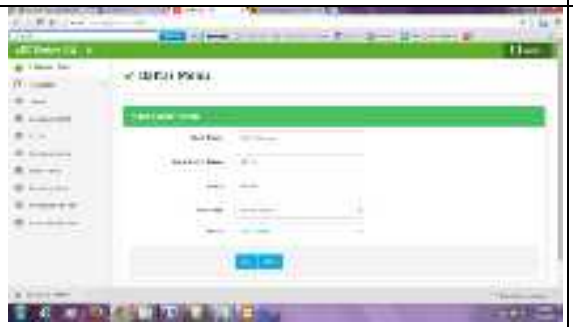 & $\begin{array}{l}\text { Data daftar menu } \\
\text { berhasil tampil } \\
\text { pada list daftar } \\
\text { menu }\end{array}$ & 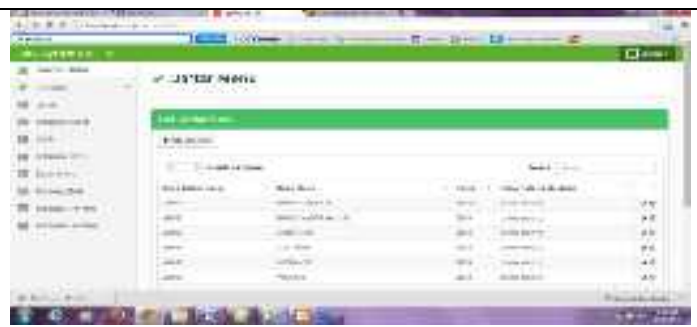 & Valid \\
\hline
\end{tabular}




\section{ISSN: 2461-1409}

\begin{tabular}{|c|c|c|c|c|c|}
\hline 4 & $\begin{array}{l}\text { Berhasil } \\
\text { input } \\
\text { kelompok } \\
\text { menu }\end{array}$ & 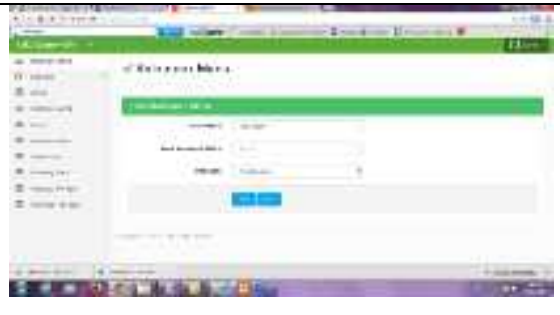 & $\begin{array}{l}\text { Data kelompok } \\
\text { menu tampil di } \\
\text { list kelompok } \\
\text { menu }\end{array}$ & 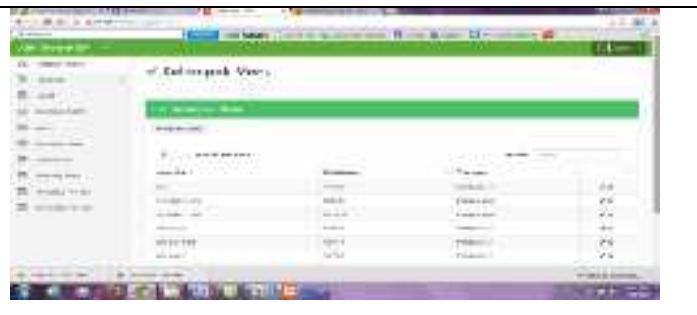 & Valid \\
\hline 5 & $\begin{array}{l}\text { Berhasil } \\
\text { input } \\
\text { transaksi } \\
\text { penjualan } \\
\text { pada form } \\
\text { pemasukan }\end{array}$ & 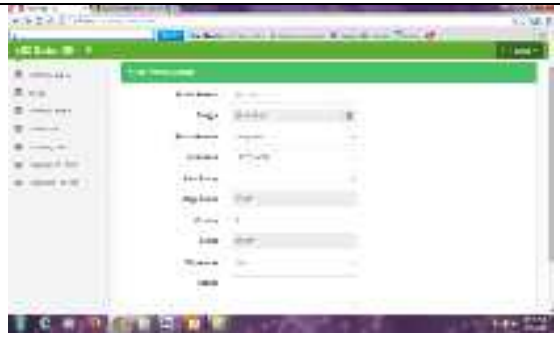 & $\begin{array}{l}\text { Hasil input } \\
\text { langsung masuk } \\
\text { ke jurnal } \\
\text { penerimaan kas }\end{array}$ & 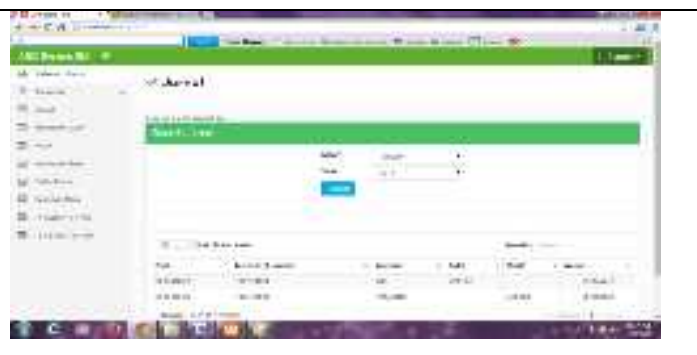 & Valid \\
\hline 6 & $\begin{array}{l}\text { Berhasil } \\
\text { input } \\
\text { transaksi } \\
\text { pembelian } \\
\text { pada form } \\
\text { pengeluaran }\end{array}$ & 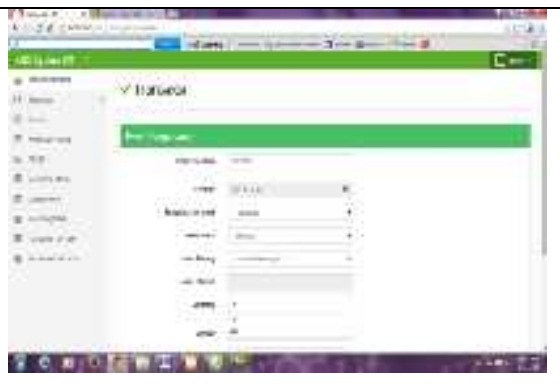 & $\begin{array}{l}\text { Hasil input } \\
\text { langsung masuk } \\
\text { ke jurnal } \\
\text { pengeluaran kas }\end{array}$ & 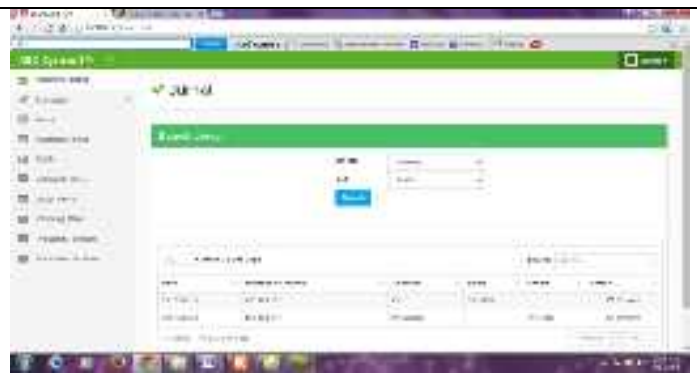 & Valid \\
\hline 7 & $\begin{array}{l}\text { Berhasil } \\
\text { tampilkan } \\
\text { penjualan } \\
\text { per item }\end{array}$ & 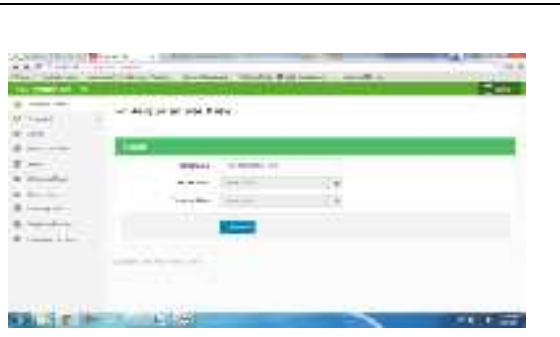 & $\begin{array}{l}\text { Penjualan per } \\
\text { item ditampilkan }\end{array}$ & 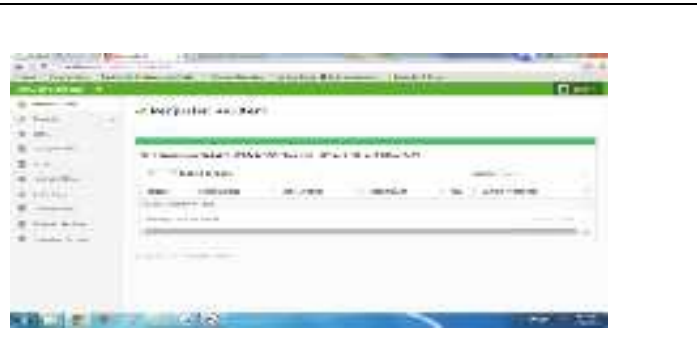 & Valid \\
\hline
\end{tabular}




\section{ISSN: 2461-1409}

\begin{tabular}{|c|l|l|l|l|l|}
\hline 8 & $\begin{array}{l}\text { Berhasil } \\
\text { tampilkan } \\
\text { pembelian } \\
\text { per item }\end{array}$ & $\begin{array}{l}\text { Pembelian per } \\
\text { item ditampilkan. }\end{array}$ & & Valid \\
& & 0 & & & \\
\hline
\end{tabular}




\subsection{Implementasi}

Kegiatan implementasi sistem dibagi dalam beberapa tahap yang digambarkan sebagai berikut.

a. Internal test

Pada tahap ini dilakukan blackbox testing oleh peneliti sendiri terhadap rancangan fungsional untuk menguji kesesuaian aplikasi dengan kebutuhan user dan uji error pada aplikasi tersebut dan dijabarkan pada pengujian aplikasi. Tahap ini dilakukan selama 1 hari.

b. Presentasi stakeholder

Pada tahap ini dilakukan penyajian awal dan pelatihan awal dari program yang telah diuji kepada stakeholder selama 1 hari. Hal ini dilakukan agar aplikasi dapat diajukan ketahap berikutnya.

c. User Acceptance Test

Pada tahap ini diadakan migrasi data manual dalam arsip ke dalam aplikasi dan implementasikan selama 1 minggu untuk diuji coba oleh user untuk penyesuaian dan revisi minor seperti validasi input pada form pengisian, tata letak warna dan menu.

d. Revisi User Acceptance Test

Pada tahap ini dilakukan revisi minor seperti validasi input pada form pengisian, tata letak warna dan menu sesuai dengan revisi dari tahap user acceptance. Tahap ini dilakukan selama 7 hari.

e. Dokumentasi

Pada tahap ini dibuat finalisasi dokumentasi dari program berbentuk buku panduan penggunaan atau manual penggunaan aplikasi. Tahap ini dilaksanakan selama 2 hari.

f. Training

Pada tahap ini dilakukan pelatihan secara komperehensif selama 2 hari untuk penggunaan aplikasi.

g. Go live

Pada tahap ini dilakukan migrasi total dari penginputan data sampai pengarsipan dokumen yang awalnya berbentuk tulisan dan kertas. Setelah itu aplikasi diimplementasikan dan dipakai oleh user sesuai dengan jadwal penelitian aplikasi.

\section{KESIMPULAN}

Berdasarkan identifikasi masalah yang terdapat di rumah makan SM, maka ditarik beberapa kesimpulan sebagai berikut:

1. Aplikasi laporan keuangan masih menggunakan database Ms Acess kemudian diolah kembali ke Ms excel. Laporan baru berupa laporan pengeluaran kas dan pemasukan kas. Belum tersusun laporan neraca dan perubahan modal. Karenanya dibutuhkan sistem yang memiliki integrasi yang tinggi yang bisa memenuhi kebutuhan manajemen.

2. Sistem telah memiliki fasilitas laporan rugi laba namun hanya secara global, belum merinci per menu atau produk. Sehingga untuk mengetahui laba rugi per produk diperlukan sistem informasi yang memenuhi kriteria tersebut. Untuk itu digunakanlah metode activity based costing system yang dianggap mampu memudahkan manajemen dalam mengendalikan biaya dan sebagai alat bantu dalam pengambilan keputusan strategis. 
3. Penelitian dimulai dengan melakukan analisa laporan keuangan yang sedang berjalan, elisitasi untuk mengetahui kebutuhan sistem, kemudian menganalisa metode $\mathrm{ABC}$, mengidentifikasi aktivitas produksi dan merancang penerapan metode ABC ke dalam aplikasi laporan keuangan. Selanjutnya mendesain formform laporan lalu menguji kelayakan sistem dan diakhiri pada tahap implementasi dan perawatan sistem. Perancangan program menggunakan tools UML (Unified Modeling Language) yaitu Use Case Diagram, Sequence Diagram, Activity Diagram, dengan software Visual Paradigm 6.4 enterprise edition. Serta menggunakan bahasa pemrogramman PHP (Hypertext Preprocessor) dengan Framework CodeIgniter (CI) dan pembuatan database pada MySQL.

\section{SARAN}

Berikut ini adalah saran-saran yang perlu diperhatikan, yang bisa menjadi dijadikan sebagai bahan pertimbangan bagi penelitian lebih lanjut dikemudian hari yaitu:

1. Diperlukan keamanan data dengan schedule backup data secara rutin, hal ini sangat penting jika terjadi kesalahan (error) pada komputer, ataupun disebabkan gangguan listrik secara menyeluruh, maka dengan adanya backup data tersebut tidak hilang.

2. Setelah sistem diimplementasikan, maka pasti dibutuhkan suatu pengembangan sistem yang baru, agar kekurangan pada sistem ini dapat diperbaiki maupun ditambah serta dapat sejalan dengan perkembangan ilmu teknologi yang semakin canggih.

\section{DAFTAR PUSTAKA}

[1] Rudianto, “Akuntansi Manajemen, Informasi Untuk Pengambilan Keputusan Strategis" Jakarta : Erlangga, 2013

[2] Simamora, Henry. 2002. Akuntansi Manajemen. Jakarta Selatan: UPP AMP YKPN.

[3] Ramdhani, Dadan, SE., M. Si., Akt., "Dasar-Dasar Akuntansi", Markumi Lintas Pustaka, cetakan 1 april 2011

[4] Kamalia tri Utami, Kamalia Tri, "Perancangan Sistem Informasi Laporan Keuangan APBD Pada Dinas Pendidikan Menggunakan Program Visual Basic 6.0”, Tangerang: STMIK RAHARJA, 2009

[5] Rohmi, Siti Saridatur, "Perancangan Sistem Informasi Laporan Keuangan Pada PT. Tangerang Tirta Manunggal", Tangerang: STMIK RAHARJA, 2010

[6] Hartati, Sudi, "Perancangan Sistem Penyajian Laporan Realisasi Anggaran Pada Badan Pusat Statistik Kota Tangerang", Tangerang: STMIK RAHARJA, 2010

[7] Sadewo, Lanang, "Design Penerapan Activity Based Costing System Untuk Menentukan Harga Pokok Produksi”, Jakarta: UIN Syarif Hidayatullah, 2013.

[8] Prakoso, Koko Yuli, "Penerapan Metode Activity Based Costing (ABC) Dengan Pendekatan Manajemen Rantai Pasok (Supply Chain Mangement) Di Pt. Kawan Sejati Akurasi (Ksa Yogya) “, Yogyakarta: UIN Sunan Kalijaga, 2012

[9] Yulianti, "Penerapan Activity Based Costing System Sebagai Dasar Penetapan Tarif Jasa Rawat Inap”, Makasar: Universitas Hasanuddin, 2011 